\title{
PENGARUH UNDANG-UNDANG NOMOR 7 TAHUN 1983 TENTANG PAJAK PENGHASILAN SEBAGAIMANA TELAH DIUBAH TERAKHIR DENGAN UNDANG-UNDANG NOMOR 36 TAHUN 2008 TERHADAP KEPATUHAN WAJIB PAJAK ORANG PRIBADI DI KANTOR WILAYAH DIREKTORAT JENDERAL PAJAK (DJP) JAWA TIMUR I
}

FARISKA SEPTARINA RAJIANTO

Sekolah Pascasarjana Fakultas Ekonomi dan Bisnis Universitas Airlangga

fariskaseptarina@yandex.com

\section{ARTICLE HISTORY}

Received:

15 June 2019

Revised

14 July 2019

Accepted:

1 August 2019

Online available:

10 November 2019

Keywords (Calibri 10):

Changes in the Income

Tax Law,

Taxable Income

Bracket, non-taxable income, income tax rates, deposit and reporting procedures,

\begin{abstract}
Tax Laws changes made Direktorat Jenderal Pajak (DJP) in order to create Tax Laws that allows taxpayers to carry out their tax obligations and in accordance with the state of today's dynamic economy. One of the Tax Laws amended is Income Tax Law seen from the taxable income bracket; non-taxable income; income tax rates; depositing and reporting procedures; tax audits; tax penalties; Taxpayer behavior; nationality; and taxpayer perceptions of the tax system significantly influence the individual taxpayer compliance in Kantor Wilayah DJP Jawa Timur I.

This study continues research Barbuta-Misu (2011) which identifies the variables of tax compliance by creating a model that comes with the factors that affect tax compliance in several countries and adapted to the conditions of the State of Rome.

The results of this study states that the taxable income bracket; nontaxable income; income tax rates; depositing and reporting procedures; and tax penalties have a significant influence on the individual taxpayer compliance. Other hand, tax audits; Taxpayer behavior; nationality; and taxpayer perceptions of the tax system that does not have a significant influence on the individual taxpayer compliance. Based on these results, the variables generated in the course of a study conducted by BarbutaMisu (2011) not all variables can affect tax compliance in accordance with the Income Tax Law in force in Indonesia.
\end{abstract}


Jurnal Ekonomi dan Bisnis Airlangga, Vol. 29, No.2, June - November 2019

\section{LATAR BELAKANG}

Pada tahun 2013, Laporan Realisasi Penerimaan Negara menyatakan bahwa total penerimaan negara adalah $\mathrm{Rp}$ 1.497.500.000.000.000,-, yang terdiri dari penerimaan pajak sebesar $\mathrm{Rp} 1.148 .300 .000 .000 .000,-(76,68 \%)$ dan penerimaan bukan pajak sebesar Rp 349.200.000.000.000,- (23,32\%). Pajak Penghasilan (PPh) 'menyumbang' sebesar 46, 92\% dalam penerimaan Negara dari pajak pada tahun 2013, yaitu $\mathrm{Rp}$ 538.800.000.000.000,-. Berdasarkan data tersebut, maka PPh memberikan kontribusi yang signifikan sebagai sumber penerimaan Negara dari pajak.

Pemerintah melakukan perubahan pada UU PPh sebanyak 4 kali, yaitu (i) Undang-undang Nomor 7 Tahun 1983; (ii) Undang-undang No. 10 Tahun 1994; (iii) Undang-undang No. 17 Tahun 2000; (iv) Undang-undang No. 36 Tahun 2008. Perubahan yang dilaksanakan oleh Pemerintah tersebut dalam lapisan Penghasilan Kena Pajak (PKP); Penghasilan Tidak Kena Pajak (PTKP); tarif PPh; tata cara penyetoran dan pelaporan; pemeriksaan pajak; dan sanksi pajak yang mengalami 'penyempurnaan'.

Menurut Utama dkk. (2011), perubahan UU PPh yang dilaksanakan Pemerintah tetap berpegang pada prinsip-prinsip perpajakan yang dianut secara universal dan tetap mempertahankan sistem self assessment. Hal ini sebagai bentuk kepercayaan untuk Wajib Pajak dalam melaksanakan kewajiban perpajakannya. Perubahan UU PPh ditunjukkan untuk meningkatkan kesadaran Wajib Pajak, sehingga Wajib Pajak dapat menyetor pajak tepat waktu, mengisi Surat Pemberitahuan (SPT) dengan tepat dan benar, serta melaporkan SPT dengan tepat waktu sebagai wujud kepatuhan Wajib Pajak.

Penelitian yang dilaksanakan oleh Barbuta-Misu (2011) untuk mengidentifikasi variabel-variabel dari tax compliance "kepatuhan terhadap peraturan perpajakan" dengan menciptakan suatu model yang dilengkapi dengan faktor-faktor yang mempengaruhi tax compliance di beberapa negara dan diadaptasi dengan kondisi Negara Roma. Maka penelitian ini menghasilkan 2 faktor penting, yaitu faktor ekonomi (lapisan penghasilan, kemungkinan terjadinya pemeriksaan, pemeriksaan pajak, tarif pajak, fasilitas pajak, sanksi adminitrasi, sanksi pidana) dan faktor non-ekonomi (sikap terhadap pajak; individu Wajib Pajak; norma sosial dan nasionalitas; keadilan yang dirasakan terhadap sistem perpajakan).

Berdasarkan uraian di atas, maka peneliti ingin meneliti mengenai pengaruh Undang-undang Nomor 7 Tahun 1983 Tentang Pajak Penghasilan Sebagaimana Telah Diubah Terakhir Dengan Undang-undang Nomor 36 Tahun 2008 dalam lapisan Penghasilan Kena Pajak (PKP); Penghasilan Tidak Kena Pajak (PTKP); tarif PPh; tata cara penyetoran dan pelaporan; pemeriksaan pajak; sanksi pajak; perilaku Wajib Pajak; nasionalitas; persepsi Wajib Pajak terhadap sistem perpajakan berpengaruh signifikan terhadap kepatuhan Wajib Pajak Orang Pribadi di Kantor Wilayah Direktorat Jenderal Pajak Jawa Timur I. 


\section{TINJAUAN PUSTAKA}

Menurut UU PPh Pasal 6, Penghasilan Kena Pajak (PKP) adalah penghasilan bruto setalah dikurangi dengan biaya-biaya untuk mendapatkan, menagih, dan memelihara penghasilan. Tetapi ada PKP yang diatur khusus dalam Peraturan Pemerintah, seperti Peraturan Pemerintah Nomo 46 Tahun 2013Tentang Pajak Penghasilan atas Penghasilan dari Usaha yang Diterima atau Diperoleh Wajib Pajak yang memiliki Peredaran Bruto Tertentu Tanggal 12 Juni 2013, berlaku sejak 1 Juli 2013 berupa penghasilan bruto.

Penghasilan Tidak Kena Pajak (PTKP) merupakan jumlah penghasilan tertentu yang tidak dikenai pajak (Resmi, 2011:95). Untuk menentukan besarnya Penghasilan Kena Pajak, dapat dihitung dengan mengurangi penghasilan Wajib Pajak dengan PTKP. Adapun besaran PTKP ini dapat dilihat pada Pasal 7 ayat 1 UU PPh.

Surat Setoran Pajak (SSP) berfungsi sebagai bukti pembayaran pajak apabila telah disahkan oleh pejabat kantor penerima pembayaran yang berwenang atau apabila telah mendapatkan validasi. Pembayaran dan penyetoran pajak harus dilakukan dengan menggunakan Surat Setoran Pajak atau sarana administrasi lain yang disamakan dengan Surat Setoran Pajak. Surat Setoran Pajak atau sarana administrasi lain dianggap sah apabila telah divalidasi dengan Nomor Transaksi Penerimaan Pajak (NTPN).

Surat Pemberitahuan (SPT) adalah surat yang oleh Wajib Pajak digunakan untuk melaporkan penghitungan dan/atau pembayaran pajak, objek pajak dan atau bukan objek pajak dan atau harta dan kewajiban, menurut ketentuan peraturan perundangundangan perpajakan. Ada 2 macam SPT, yaitu (i) SPT Masa adalah Surat Pemberitahuan untuk suatu Masa Pajak; (ii) SPT Tahunan adalah Surat Pemberitahuan untuk suatu Tahun Pajak atau Bagian Tahun Pajak.

SPT wajib diisi secara benar, jelas, lengkap, dan harus ditandatangani. Dalam hal SPT diisi dan ditandatangani oleh orang lain bukan WP, harus dilampiri surat kuasa khusus. Untuk Wajib Pajak Badan, SPT harus ditandatangani oleh pengurus/direksi.

SPT dapat disampaikan secara langsung atau melalui Pos secara tercatat ke KPP atau KP4 setempat, atau melalui jasa ekspedisi atau jasa kurir yang ditunjuk oleh Direktur Jenderal Pajak. Batas waktu penyampaian antara lain:

1. SPT Tahunan WP OP adalah pada akhir bulan ketiga setelah berakhirnya tahun atau bagian tahun pajak.

2. SPT Tahunan PPh Wajib Pajak Badan adalah pada akhir bulan keempat setelah berakhirnya tahun atau bagian tahun pajak.

SPT yang disampaikan langsung ke KPP/KP4 diberikan bukti penerimaan. Dalam hal SPT disampaikan melalui pos secara tercatat, bukti serta tanggal pengiriman dianggap sebagai bukti penerimaan. 
Jurnal Ekonomi dan Bisnis Airlangga, Vol. 29, No.2, June - November 2019

Pemeriksaan adalah serangkaian kegiatan menghimpun dan mengolah data, keterangan, dan/atau bukti yang dilaksanakan secara objektif dan profesional berdasarkan suatu standar pemeriksaan untuk menguji kepatuhan pemenuhan kewajiban perpajakan dan/atau untuk tujuan lain dalam rangka melaksanakan ketentuan peraturan perundang-undangan perpajakan.

Tujuan dilakukannya pemeriksaan adalah:

1. Menguji kepatuhan pemenuhan kewajiban perpajakan,

2. Tujuan lain, seperti pemberian Nomor Pokok Wajib Pajak secara jabatan; penghapusan NPWP; pengukuhan Pengusaha Kena Pajak (PKP) dan pencabutan PKP; Wajib Pajak mengajukan keberatan; pengumpulan bahan untuk penyusunan Norma Penghitungan Penghasilan Neto; pencocokan data dan/atau alat keterangan; penentuan Wajib Pajak berlokasi di daerah terpencil; penentuan satu atau lebih tempat terutang PPN; pemeriksaan dalam rangka penagihan pajak; penentuan saat mulai berproduksi sehubungan dengan fasilitas perpajakan dan/ atau; pemenuhan permintaan informasi dari negara mitra Perjanjian Penghindaran Pajak Berganda (P3B).

Menurut Aris Aviantara, et al. (2011), pengetahuan tentang sanksi dalam perpajakan menjadi penting karena pemerintah Indonesia memilih menerapkan self assessment dalam rangka pelaksanaan pemungutan pajak. Berdasarkan sistem ini, Wajib Pajak diberikan kepercayaan untuk menghitung menyetor, dan melaporkan pajaknya sendiri.

Pada hakikatnya, pengenaan sanksi perpajakan diberlakukan untuk menciptakan kepatuhan Wajib Pajak dalam melaksanakan kewajiban perpajakannya. Ada 2 macam sanksi perpajakan, yaitu:

1. Sanksi Administrasi yang terdiri dari Denda dan Bunga.

2. Sanksi Pidana.

Asas nasionalitas melihat pada status kewarganegaraan dari orang atau badan yang memperoleh penghasilan. Berdasarkan asas ini, sumber penghasilan yang akan dikenakan pajak tidak menjadi persoalnya, karena dilakukan dengan cara menggaabungkan asas nasionalitas dengan konsep pengenaan pajak atas world wide income.

Masyarakat Indonesia yang sudah termasuk dalam Subyek PPh sesuai dengan UU PPh harus mendaftarkan diri sebagai Wajib Pajak yang ditandai dengan kepemilikan NPWP (Nomor Pokok Wajib Pajak) yang dikeluarkan oleh Kantor Pelayanan Pajak (KPP) tempat Wajib Pajak mendaftar. Setelah itu, Wajib Pajak akan melaksanakan kewajiban perpajakannya, yaitu menghitung dan menyetor PPh Terutang, dan melaporkan SPT beserta harta yang dimiliki pada akhir tahun pajak. Sistem pemungutan PPh ini disebut self-assessment. 
Menurut Utama, et al. (2011), kepatuhan dalam hal perpajakan berarti keadaan Wajib Pajak yang melaksanakan hak, dan khususnya kewajibannya, secara disiplin, sesuai dengan Peraturan Perundang-undangan serta tata cara perpajakan yang berlaku. Ada 2 jenis kepatuhan, yaitu kepatuhan formal (ketentuan umum dalam UU Perpajakan) dan kepatuhan materiil (isi dan jiwa UU Perpajakan).

\section{METODE PENELITIAN}

Gambar 1

Skema Rerangka Konseptual Penelitian

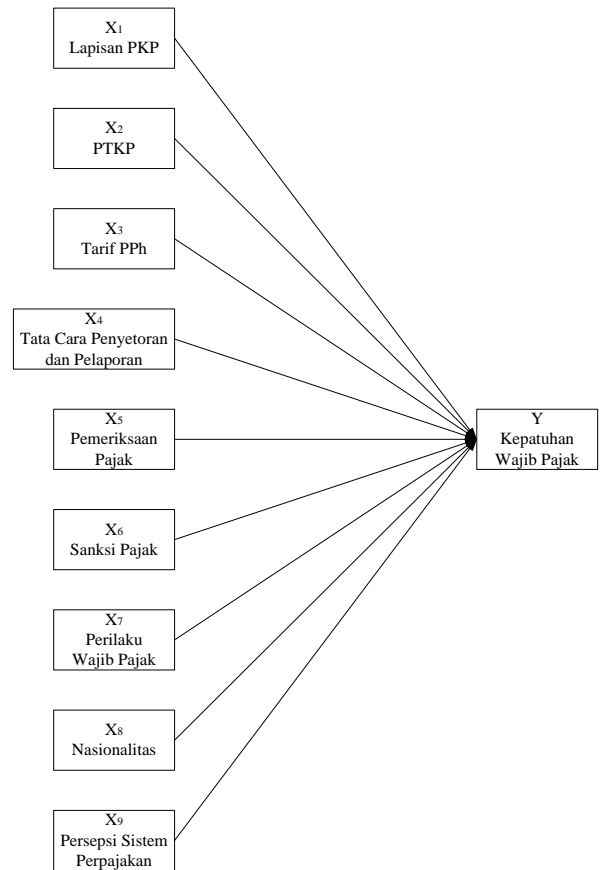

$H_{1}$ : Lapisan Penghasilan Kena Pajak (PKP) berpengaruh signifikan terhadap Kepatuhan Wajib Pajak Orang Pribadi.

$\mathrm{H}_{2}$ : Penghasilan Tidak Kena Pajak (PTKP) berpengaruh signifikan terhadap Kepatuhan Wajib Pajak Orang Pribadi.

$H_{3}$ : Tarif Pajak Penghasilan berpengaruh signifikan terhadap Kepatuhan Wajib Pajak Orang Pribadi.

$H_{4}$ : Tata Cara Penyetoran dan Pelaporan berpengaruh signifikan terhadap Kepatuhan Wajib Pajak Orang Pribadi.

$H_{5}$ : Pemeriksaan Pajak Penghasilan berpengaruh signifikan terhadap Kepatuhan Wajib Pajak Orang Pribadi.

$H_{6}$ : Sanksi Pajak berpengaruh signifikan terhadap Kepatuhan Wajib Pajak Orang Pribadi. 
$H_{7}$ : Perilaku Wajib Pajak berpengaruh signifikan terhadap Kepatuhan Wajib Pajak Orang Pribadi.

$H_{8}$ : Nasionalitas berpengaruh signifikan terhadap Kepatuhan Wajib Pajak Orang Pribadi.

$H_{9}$ : Persepsi Wajib Pajak terhadap Sistem Perpajakan berpengaruh signifikan terhadap Kepatuhan Wajib Pajak Orang Pribadi.

Desain penelitian ini mengarah pada studi pengujian hipotesis. Penelitian ini menggunakan kuisioner untuk mengetahui kepatuhan Wajib Pajak. Kuisioner akan berisi pernyataan yang tersusun dan responden akan menjawab kuisioner dengan menggunakan skala Likert 1 sampai dengan 5 (1=sangat tidak setuju, $5=$ sangat setuju) untuk mengetahui opini Wajib Pajak mengenai perubahan Undang-undang Nomor 7 Tahun 1983 Tentang Pajak Penghasilan Sebagaimana Telah Diubah Terakhir Dengan Undang-undang Nomor 36 Tahun 2008 dalam Lapisan Penghasilan Kena Pajak (PKP); Penghasilan Tidak Kena Pajak (PTKP); tarif Pajak Penghasilan (PPh); Tata Cara Penyetoran dan Pelaporan PPh; Pemeriksaan PPh; Sanksi; Perilaku Wajib Pajak; Nasionalitas; dan Persepsi Wajib Pajak terhadap sistem perpajakan.

Populasi dalam penelitian ini adalah Wajib Pajak Orang Pribadi yang terdaftar di Kantor Wilayah Direktorat Jenderal Pajak (DJP) Jawa Timur I per 2013 sebanyak 420.010 Wajib Pajak Orang Pribadi.

Responden dalam penelitian ini adalah Wajib Pajak Orang Pribadi sebagai pihak yang menjalankan kewajiban perpajakan secara mandiri (Wajib Pajak efektif) sebanyak 378.333 Wajib Pajak Orang Pribadi di Kantor Wilayah DJP Jawa Timur I per 2013.

Kuisioner akan disebarkan pada Wajib Pajak Orang Pribadi yang dilakukan dengan simple random probability sampling, dengan menggunakan rumus Slovin untuk menentukan ukuran sampel. Hal ini karena semua Wajib Pajak mempunyai probabilitas yang sama untuk membayar Pajak Penghasilan.

Menurut Sujarweni dan Endrayanto (2012:17), rumus Slovin, maka ditentukan jumlah sampel sebesar 100 dengan perhitungan sebagai berikut:

$$
n=\frac{378.333}{1+\left(378.333 \times 0,1^{2}\right)}=99,974 \text { dibulatkan } 100
$$

Teknik Analisis Data

Uji reliabilitas dan validitas digunakan untuk mengetahui kelayakan butir-butir dalam suatu daftar pernyataan di kuisioner yang diisi oleh responden tersebut dapat digunakan untuk mengambil data.

Uji Asumsi Klasik berupa uji normalitas, uji multikolinearitas, uji autokorelasi, dan uji heteroskedastisitas harus dilakukan, karena peneliti menggunakan metode regresi berganda. Metode Regresi Linear Berganda dilakukan untuk menguji pengaruh Reformasi Undang-undang Pajak Penghasilan dalam perubahan lapisan Penghasilan Kena 
Pajak (PKP); Penghasilan Tidak Kena Pajak (PTKP); tarif PPh; tata cara penyetoran dan pelaporan; pemeriksaan pajak; sanksi pajak; perilaku Wajib Pajak; nasionalitas; dan persepsi Wajib Pajak terhadap sistem perpajakan terhadap kepatuhan Wajib Pajak Orang Pribadi dan Badan. Penelitian ini akan menggunakan SPSS 17.0.

Analisis Regresi Linear Berganda adalah pengaruh secara linier antara dua atau lebih variabel independen dengan variabel dependen.

\section{HASIL PENELITIAN DAN ANALISA}

Table 1

Output Uji Regresi

\begin{tabular}{|c|c|c|c|c|c|c|c|c|c|c|c|}
\hline \multirow[b]{3}{*}{ Model } & \multicolumn{11}{|c|}{ Coefficients $^{2}$} \\
\hline & & \multicolumn{2}{|c|}{$\begin{array}{c}\text { Unstandardized } \\
\text { Coefficients }\end{array}$} & \multirow{2}{*}{\begin{tabular}{|c|}
$\begin{array}{l}\text { Standardized } \\
\text { Coefficients }\end{array}$ \\
Beta \\
\end{tabular}} & \multirow[b]{2}{*}{$t$} & \multirow[b]{2}{*}{ Sia. } & \multicolumn{3}{|c|}{ Correlations } & \multicolumn{2}{|c|}{ Colinearity Statistics } \\
\hline & & $\mathrm{B}$ & Sid. Error & & & & Zero-order & Partial & \begin{tabular}{|l|} 
Part \\
\end{tabular} & \begin{tabular}{|l|l|} 
Tolerance \\
\end{tabular} & $\mathrm{VF}$ \\
\hline 11 & (Constant) & .624 & .379 & & -1.649 & .103 & & & & & \\
\hline & Lapisan PKP (X1) & .198 & .071 & 197 & 2.800 & .006 & .579 & .283 & 153 & .603 & 1.658 \\
\hline & $\operatorname{PTKP}\left(X_{2}\right)$ & 164 & 071 & 147 & 2.314 & .023 & .518 & .237 & .126 & .732 & 1.367 \\
\hline & $\operatorname{TarifPPh}\left(X_{3}\right)$ & .340 & .072 & .370 & 4.738 & .000 & .716 & .447 & .258 & .488 & 2.047 \\
\hline & Tata Cara Penyetoran \& Pelaporan PPh (X4) & .243 & .067 & .242 & 3.624 & .000 & .594 & .357 & .198 & .667 & 1.500 \\
\hline & Pemeriksaan Pajak (X5) & 107 & 071 & .08 & 1.510 & .134 & .590 & 157 & .082 & .577 & 1.734 \\
\hline & Sanks Pajak (X6) & .254 & .070 & .234 & 3.634 & .000 & .495 & .358 & 198 & .715 & 1.398 \\
\hline & Perilaku WP (X7) & .118 & .067 & .116 & -1.779 & .079 & .295 & .184 & .097 & .694 & 1.441 \\
\hline & Nasionalitas (X8) & .055 & .059 & .058 & .933 & .353 & .357 & .098 & .051 & .764 & 1.309 \\
\hline & Persepsi Thd. Sistem Perpajakan $(X 9)$ & .028 & .086 & .021 & .324 & .746 & .436 & .034 & .018 & .688 & 1.454 \\
\hline
\end{tabular}

a. Dependent Variable: Kepatuhan WP (M

\begin{tabular}{|c|c|c|c|c|c|c|}
\hline \multicolumn{7}{|c|}{ ANOVAP } \\
\hline \multirow{4}{*}{\begin{tabular}{|l}
$M$ \\
1
\end{tabular}} & & $\begin{array}{c}\text { Sum of } \\
\text { Squares }\end{array}$ & df & Mean Square & & Sig. \\
\hline & Regression & 27.663 & 9 & 3.074 & 27.386 & $.000^{\mathrm{a}}$ \\
\hline & Residual & 10.101 & 90 & .112 & & \\
\hline & Total & 37.764 & 99 & & & \\
\hline
\end{tabular}

a. Predictors: (Constant), Persepsi Thd. Sistem Perpajakan (X9), Perilaku WP (X7),

Nasionalitas (X8), PTKP (X2), Tata Cara Penyetoran \& Pelaporan PPh (X4), Sanks

Pajak (X6), Lapisan PKP (X1), Pemeriksaan Pajak (X5), Tarif PPh (X3)

b. Dependent Variable: Kepatuhan WP $(Y)$

\begin{tabular}{|l|r|r|r|r|r|}
\hline \multicolumn{7}{|c|}{ Model Summary $^{\text {Model }}$} & \multicolumn{1}{|c|}{$\mathrm{R}$} & R Square & $\begin{array}{c}\text { Adjusted } \\
\text { R Square }\end{array}$ & $\begin{array}{c}\text { Std. Error of } \\
\text { the Estimate }\end{array}$ & $\begin{array}{c}\text { Durbin- } \\
\text { Watson }\end{array}$ \\
\hline 1 & $.856^{\mathrm{a}}$ & .733 & .706 & .33502 & 1.618 \\
\hline
\end{tabular}

Berdasarkan Tabel 1, model persamaan regresi yang dihasilkan adalah:

$Y=-0.624+0.198 X 1+0.164 X 2+0.340 X 3+0.243 X 4+0.107 X 5+0.254 X 6-0.118 X 7-$ $0.055 \times 8+0.028 \times 9$

Persamaan regresi yang dihasilkan di atas dapat dijelaskan sebagai berikut:

1. Konstanta sebesar -0,624 artinya jika Lapisan Penghasilan Kena Pajak (X1); Penghasilan Tidak Kena Pajak (X2); Tarif PPh (X3); Tata Cara Penyetoran dan Pelaporan (X4); Pemeriksaan Pajak (X5); Sanksi Pajak (X6); Perilaku Wajib 
Pajak (X7); Nasionalitas (X8); dan Persepsi Wajib Pajak terhadap Sistem Perpajakan (X9) nilainya adalah 0, maka Kepatuhan Wajib Pajak Orang Pribadi (Y) mengalami penurunan sebesar adalah 0,624 (62,4\%).

2. Koefisien regresi variabel Lapisan Penghasilan Kena Pajak (X1) sebesar 0,198 artinya jika variabel independen lain nilainya tetap dan Lapisan Penghasilan Kena Pajak mengalami kenaikan nilai 1, maka Kepatuhan Wajib Pajak Orang Pribadi akan mengalami peningkatan sebesar 0,198 (19,8\%).

3. Koefisien regresi variabel Penghasilan Tidak Kena Pajak (X2) sebesar 0,164 artinya jika variabel independen lain nilainya tetap dan Penghasilan Tidak Kena Pajak mengalami kenaikan nilai 1, maka Kepatuhan Wajib Pajak Orang Pribadi akan mengalami peningkatan sebesar 0,164 (16,4\%).

4. Koefisien regresi variabel Tarif PPh (X3) sebesar 0,340 artinya jika variabel independen lain nilainya tetap dan Tarif PPh mengalami kenaikan nilai 1, maka Kepatuhan Wajib Pajak Orang Pribadi akan mengalami peningkatan sebesar 0,340 (34,0\%).

5. Koefisien regresi variabel Tata Cara Penyetoran dan Pelaporan (X4) sebesar 0,243 artinya jika variabel independen lain nilainya tetap dan Tata Cara Penyetoran dan Pelaporan mengalami kenaikan nilai 1, maka Kepatuhan Wajib Pajak Orang Pribadi akan mengalami peningkatan sebesar 0,243 (24,3\%).

6. Koefisien regresi variabel Pemeriksaan Pajak (X5) sebesar 0,107 artinya jika variabel independen lain nilainya tetap dan Pemeriksaan Pajak mengalami kenaikan nilai 1, maka Kepatuhan Wajib Pajak Orang Pribadi akan mengalami peningkatan sebesar 0,107 (10,7\%).

7. Koefisien regresi variabel Sanksi Pajak (X6) sebesar 0,254 artinya jika variabel independen lain nilainya tetap dan Sanksi Pajak mengalami kenaikan nilai 1, maka Kepatuhan Wajib Pajak Orang Pribadi akan mengalami peningkatan sebesar $0,254(25,4 \%)$.

8. Koefisien regresi variabel Perilaku Wajib Pajak (X7) sebesar -0,118 artinya jika variabel independen lain nilainya tetap dan Perilaku Wajib Pajak mengalami kenaikan nilai 1, maka Kepatuhan Wajib Pajak Orang Pribadi akan mengalami penurunan sebesar 0,118 (11,8\%).

9. Koefisien regresi variabel Nasionalitas (X8) sebesar -0,055 artinya jika variabel independen lain nilainya tetap dan Nasionalitas mengalami kenaikan nilai 1, maka Kepatuhan Wajib Pajak Orang Pribadi akan mengalami penurunan sebesar 0,055 (5,5\%).

10. Koefisien regresi variabel Persepsi Wajib Pajak terhadap Sistem Perpajakan (X9) sebesar 0,028 artinya jika variabel independen lain nilainya tetap dan 
Persepsi Wajib Pajak terhadap Sistem Perpajakan mengalami kenaikan nilai 1, maka Kepatuhan Wajib Pajak Orang Pribadi akan mengalami peningkatan sebesar $0,028(2,8 \%)$.

11. Residual atau error term (e) adalah perbedaan antara nilai variabel Kepatuhan Wajib Pajak (Y) yang sebenarnya dan nilai prediksi (predicted value) pada masing-masing responden. Semakin kecil angka residual dibandingkan standardised residual (residual yang distandarkan), maka model regresi semakin baik untuk digunakan dalam memprediksi (Sarwono, 2013:105).

Pada penelitian ini, persamaan regresi yang dihasilkan menunjukkan kalau model regresi baik digunakan dalam memprediksi. Hal ini terlihat dimana 100 responden mempunyai nilai residual yang lebih kecil daripada standardised residual.

Hasil pertama penelitian ini, Lapisan Penghasilan Kena Pajak (PKP) mempunyai pengaruh yang signifikan terhadap kepatuhan Wajib Pajak Orang Pribadi di Kantor Wilayah DJP Jawa Timur I. Hal ini disebabkan karena Lapisan PKP yang berubah dalam UU PPh akan mempengaruhi jumlah Pajak Penghasilan terutang yang akan dibayar oleh Wajib Pajak Orang Pribadi karena tarif Pajak Penghasilan bersifat progresif.

Hasil kedua penelitian ini, Penghasilan Tidak kena Pajak (PTKP) mempunyai pengaruh yang signifikan terhadap kepatuhan Wajib Pajak Orang Pribadi di Kantor Wilayah DJP Jawa Timur I. Semakin besar jumlah PTKP yang ditentukan oleh Direktorat Jenderal Pajak, maka semakin kecil jumlah PKP Wajib Pajak Orang Pribadi tersebut

Hasil ketiga penelitian ini, tarif Pajak Penghasilan mempunyai pengaruh yang signifikan terhadap kepatuhan Wajib Pajak Orang Pribadi di Kantor Wilayah DJP Jawa Timur I. Hal ini disebabkan karena tarif berperan sangat penting untuk menetukan jumlah pajak terutang, selain Lapisan PKP.

Hasil keempat penelitian ini, Tata Cara Penyetoran dan Pelaporan Pajak Penghasilan mempunyai pengaruh yang signifikan terhadap kepatuhan Wajib Pajak Orang Pribadi di Kantor Wilayah DJP Jawa Timur I. Tata Cara Penyetoran dan Pelaporan Pajak Penghasilan yang susah dipahami dan dilaksanakan oleh Wajib Pajak Orang Pribadi akan menurunkan kepatuhan Wajib Pajak karena melaksanakannya tidak sesuai dengan peraturan.

Hasil kelima penelitian ini, pemeriksaan pajak mempunyai pengaruh yang tidak signifikan terhadap kepatuhan Wajib Pajak Orang Pribadi di Kantor Wilayah DJP Jawa Timur I.

Hasil keenam penelitian ini, sanksi pajak mempunyai pengaruh yang signifikan terhadap kepatuhan Wajib Pajak Orang Pribadi di Kantor Wilayah DJP Jawa Timur I. Hal ini disebabkan karena sanksi administrasi maupun sanksi pidana yang berat akan mempengaruhi kepatuhan Wajib Pajak, terutama dalam melaksanakan kewajiban perpajakannya. 
Hasil ketujuh penelitian ini, perilaku Wajib Pajak mempunyai pengaruh yang tidak signifikan terhadap kepatuhan Wajib Pajak Orang Pribadi di Kantor Wilayah DJP Jawa Timur I.

Hasil kedelapan penelitian ini, nasionalitas mempunyai pengaruh yang tidak signifikan terhadap kepatuhan Wajib Pajak Orang Pribadi di Kantor Wilayah DJP Jawa Timur I. Pemahaman yang berbeda mengenai manfaat dari pembayaran pajak antara Peraturan Perpajakan dengan Wajib Pajak, dimana manfaat dari pembayaran pajak tidak dapat dirasakan secara langsung.

Hasil kesembilan penelitian ini, persepsi Wajib Pajak terhadap sistem perpajakan mempunyai pengaruh yang tidak signifikan terhadap kepatuhan Wajib Pajak Orang Pribadi di Kantor Wilayah DJP Jawa Timur I. Sistem perpajakan yang ada saat ini belum berjalan secara maksimal dan efektif, padahal ini dapat dijadikan 'pancingan' untuk meningkatkan kepatuhan Wajib Pajak.

Terakhir penelitian ini menemukan tarif Pajak Penghasilan (PPh); Penghasilan Tidak Kena Pajak (PTKP); lapisan Penghasilan Kena Pajak (PKP); tata cara penyetoran dan pelaporan; standar pemeriksaan; sanksi pajak; perilaku Wajib Pajak, nasionalitas; persepsi Wajib Pajak terhadap sistem perpajakan mempunyai pengaruh yang signifikan terhadap kepatuhan Wajib Pajak Orang Pribadi di Kantor Wilayah DJP Jawa Timur I.

Penelitian ini juga membuktikan bahwa penelitian Utama dkk. (2011) yang menyatakan bahwa perubahan dalam lapisan PKP, PTKP, dan tarif PPh mempunyai pengaruh terhadap kepatuhan Wajib Pajak Orang Pribadi sesuai dengan hasil pertama, kedua, dan ketiga dalam penelitian ini. Selain itu, penelitian ini juga menyatakan bahwa penelitian Barbuta-Misu (2011) yang mengidentifikasi faktor-faktor yang mempengaruhi tax compliance di Negara Roma tidak sesuai dengan UU PPh yang berlaku di Indonesia. Hal ini dibuktikan dengan pemeriksaan pajak; perilaku Wajib Pajak; nasionalitas; dan persepsi Wajib Pajak terhadap sistem perpajakan tidak berpengaruh signifikan terhadap kepatuhan Wajib Pajak Orang Pribadi di Kantor Wilayah DJP Jawa Timur I.

\section{CONCLUSION}

Penelitian ini membuktikan bahwa penelitian Utama dkk. (2011) yang menyatakan bahwa perubahan dalam lapisan PKP, PTKP, dan tarif PPh mempunyai pengaruh terhadap kepatuhan Wajib Pajak Orang Pribadi sesuai dengan hasil pertama, kedua, dan ketiga dalam penelitian ini. Selain itu, penelitian ini juga menyatakan bahwa penelitian Barbuta-Misu (2011) yang mengidentifikasi faktor-faktor yang mempengaruhi tax compliance di Negara Roma tidak sesuai dengan UU PPh yang berlaku di Indonesia. Hal ini dibuktikan dengan pemeriksaan pajak; perilaku Wajib Pajak; nasionalitas; dan persepsi Wajib Pajak terhadap sistem perpajakan tidak berpengaruh signifikan terhadap kepatuhan Wajib Pajak Orang Pribadi di Kantor Wilayah DJP Jawa Timur I. 


\section{REFERENCES}

Barbuta-Misu, Nicoleta. 2011. A Review of Factors for Tax Compliance. Annals of "Dunarea de Jos" University of Galati Fascicle I. Economics and Applied Informatics. (Maret, Years XVII, No. 1/2011): 69-76.

Chandra, Andi. 2012. Kenaikan PTKP, diakses melalui http://www.pajak.go.id/content/article/kenaikan-ptkp pada tanggal 1 Mei 2014.

Direktorat Jenderal Pajak. 2012. Reformasi Pajak, Rakyat Dapat Apa?, diakses melalui http://www.pajak.go.id/content/reformasi-pajak-rakyat-dapat-apa pada tanggal 8 Mei 2014.

Komarawati, D. Rina, dan Mukhtaruddin. 2014. Analisis Tingkat Kepatuhan Wajib Pajak Orang Pribadi Terhadap Tingkat Penerimaan Pajak di Kabupaten Lahat, diakses melalui http://asp.trunojoyo.ac.id/wp-content/uploads/2014/02/AnalisisTingkat-Kepatuhan-Wajib-Pajak-Orang-Pribadi-Terhadap-Tingkat-PenerimaanPajak.pdf pada tanggal 1 Mei 2014.

Pohan, C.A. 2013. Manajemen Perpajakan. Jakarta: PT Gramedia Pustaka Utama.

R.I. Direktorat Jendral Pajak. 2011. Susunan Dalam Satu Naskah Undang-undang Perpajakan. Direktorat Penyuluhan Pelayanan dan Humas.

Sarwono, Jonathan. 2013. 12 Jurus Ampuh SPSS untuk Riset Skripsi. Jakarta: PT. Elex Media Komputindo.

Smith, Adam. 1776. An Inquiry into the Nature and Causes of the Wealth of Nations, diakses melalui http://dealyudh.student.umm.ac.id/2010/08/12/asaspemungutan-pajak/ pada tanggal 13 Agustus 2014.

Sujarweni, V.W., dan P. Endrayanto. 2012. Statistika untuk Penelitian. Yogyakarta: Graha Ilmu.

Utama, Rizky A., A. Sandra, dan J. Sangaji. 2011. Analisis Kepatuhan Wajib Pajak Orang Pribadi Usahawan Akibat Perubahan UU PPh No. 36/2008, diakses melalui http://asp.trunojoyo.ac.id/wp-content/uploads/2014/02/ANALISIS-KEPATUHANWAJIB-PAJAK-ORANG-PRIBADI-USAHAWAN-AKIBAT-PERUBAHAN-UU-PPhNo.362008.pdf pada tanggal 7 April 2014.

Wahono, Sugeng. 2012. Mengurus Pajak itu Mudah. Jakarta: PT. Elex Media Komputindo 